Interpretive Social Science 



\section{Interpretive Social Science}

A READER

Edited by Paul Rabinow and William M. Sullivan

University of California Press

BERKELEY - LOS ANGELES - LONDON 
University of California Press Berkeley and Los Angeles, California University of California Press, Ltd.

London, England Copyright $\odot 1979$ by

The Regents of the University of California

ISBN 0-520-03834-7

Library of Congress Catalog Card Number: 77-085743

Printed in the United States of America 
TO ROBERT N. BELLAH

For the waking there is one world, and it is common; but sleepers turm aside each one into a world of his own.

HERACLITUS 
